\title{
Triiodothyronine Attenuates Prostate Cancer Progression Mediated by $\beta$-Adrenergic Stimulation
}

\author{
Evangelina Delgado-González, Ana Alicia Sánchez-Tusie, Giapsy Morales, Carmen Aceves, \\ and Brenda Anguiano
}

Departamento de Neurobiología Celular y Molecular, Instituto de Neurobiología, Universidad Nacional Autónoma de México, Campus Juriquilla, Querétaro, México

\begin{abstract}
Prostate cancer cells are responsive to adrenergic and thyroid stimuli. It is well established that $\beta$-adrenergic activation (protein kinase A (PKA)/CAMP response element binding protein (CREB)) promotes cancer progression, but the role of thyroid hormones is poorly understood. We analyzed the effects of $\beta$-adrenergic stimulation (isoproterenol (ISO)) and/or thyroid hormone on neuroendocrine (NE) differentiation and cell invasion, using in vivo (LNCaP tumor) and in vitro models (LNCaP and DU145 human cells). Nude mice were inoculated with LNCaP cells and were treated for 6 wks with ISO (200 $\mu \mathrm{g} / \mathrm{d})$, triiodothyronine (T3, $2.5 \mu \mathrm{g} / \mathrm{d}$ ) or both. ISO alone reduced tumor growth but increased tumor expression of CAMP response element (CRE)-dependent genes (real-time polymerase chain reaction, chromogranin A, neuron-specific enolase, survivin, vascular endothelial growth factor (VEGF), urokinase plasmin activator (UPA) and metalloproteinase-9 (MMP-9)) and some proteins related to NE differentiation and/or invasiveness (synaptophysin, VEGF, PCREB). T3 reduced tumor growth and prevented the overexpression of ISO-stimulated factors through a pCREB-independent mechanism. In low invasive LNCaP cells, $50 \mu \mathrm{mol} / \mathrm{L}$ ISO or $100 \mathrm{nmol} / \mathrm{L}$ thyroxine (T4) induced the acquisition of NE-like morphology (phase-contrast microscopy), increased VEGF secretion (ELISA) and invasive capacity (Transwell assay), but no synergistic effects were observed after the coadministration of ISO + T4. In contrast, $10 \mathrm{nmol} / \mathrm{L}$ T3 alone had no effect, but it prevented the NE-like morphology and invasiveness stimulated by ISO. None of these treatments had any effect on highly invasive DU145 cells. In summary, this study showed that ISO and T4 increase cancer progression, and T3 attenuates ISO-stimulated progression. Further studies are required to determine if changes in the ratio of T4/T3 could be relevant for prostate cancer progression.
\end{abstract}

Online address: http://www.molmed.org

doi: 10.2119/molmed.2015.00047

\section{INTRODUCTION}

Prostate cancer is the second leading cause of cancer death in men (1). Studies over the last two decades support the notion that long-term, sympathetic activation promotes the risk of prostate cancer through multiple mechanisms. Hypertensive patients have a two-fold higher risk of developing prostate cancer than nonhypertensive patients; consistent with this observation, the risk and mortality rate decrease in patients treated for 3-5 years with adrenergic antagonists (2-7). Studies in human prostate cancer cells show that $\beta$-adrenergic/protein kinase A (PKA) activation promotes prostate cancer progression: it reduces cell proliferation (by decreasing p42-mitogen activated protein kinase [MAPK] and $\beta$-arrestin2/proto-oncogene tyrosine-protein kinase [c-Src]), and it activates survival pathways (induces phosphorylation of Bcl-2-associated death promoter [Bad] and inhibits caspases)

Address correspondence to Brenda Anguiano, Instituto de Neurobiología, UNAM Campus Juriquilla, Boulevard Juriquilla, \#3001, Querétaro, 76230, México. Phone and Fax: +52-4422381067; E-mail: anguianoo@unam.mx.

Submitted March 5, 2015; Accepted for publication February 19, 2016; Published Online (www.molmed.org) February 26, 2016.

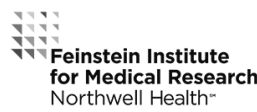

and cell migration (activates MAPK) (8-10). In agreement with this, studies in $\mathrm{BALB} / \mathrm{c}$ nude mice grafted with highly invasive PC-3 prostate cancer cells show that $\beta$-adrenergic stimulation increases the number of metastases to lymph nodes, whereas sympathectomy has the opposite effect $(11,12)$. A reduction in the time of tumor onset has also been observed in mice deficient in $\beta$-adrenergic receptors ( $A d r \beta 2^{-/-}$and $A d r \beta 3^{-/-}$) (12). In low invasive LNCaP cells, $\beta$-adrenergic stimulation induces the acquisition of a highly malignant neuroendocrine (NE) phenotype. NE prostate tumors exhibit neurite-like (NE-like) projections; they synthesize and secrete amines and peptides, are androgenreceptor negative and apoptosis resistant $(8,9,13,14)$. In humans, $\beta 2$-adrenergic receptors (ADR- $\beta 2$ ) are highly expressed in androgen-refractory metastatic tumors and are strongly associated with 
malignancy (15). A pilot study in prostate biopsies showed an association between high levels of circulating epinephrine (>1 nmol/L) and phosphorylation of a target of PKA, the cAMP response element binding protein (pCREB) (16). NE-like cells can be present in either primary tumors or metastases of patients with prostate cancer, and these are notorious for being highly aggressive and resistant to hormonal therapy and cytotoxic agents $(17,18)$.

Thyroid hormone effects in cancer remain poorly understood. In some carcinomas, thyroxine (T4) and triiodothyronine (T3) exert protumoral effects, stimulating cell proliferation and angiogenesis by nuclear (thyroid hormone receptors TR $\alpha$ and TR $\beta 1$ ) and/or nonnuclear mechanisms ( $\alpha$ v $\beta 3$ integrin receptor/activation of MAPK and phosphoinositide 3-kinase [PI3K] pathways) (19-22). In contrast, in other types of cancer, T3 induces cell arrest (decreased Ras/increased cyclin-dependent kinase inhibitor [p27 $\left.{ }^{\mathrm{kip}}\right]$ ) and apoptosis (decreased senescence marker protein [SMP30]), and it promotes cell differentiation (23-25). Studies in LNCaP cells show that T3 increases cell proliferation and secretion of proteins of the prostate epithelium (26-28), but their involvement in cancer has not yet been demonstrated. Catecholamines and thyroid hormones act synergistically to regulate metabolism, but how they interact in cancer has not been analyzed. In any case, prostate gland is responsive to adrenergic and thyroid stimuli; on the other hand, T3 decreases activity of pCREB (29). Thus, the aim of the present study was to analyze the effects of $\beta$-adrenergic stimulation (isoproterenol [ISO]) and thyroid hormone, alone and combined, on cancer progression using in vivo and in vitro approaches.

\section{MATERIALS AND METHODS}

\section{Reagents}

T4, T3 and T3 antibody and ISO bitartrate salt were obtained from Sigma. ${ }^{125} \mathrm{I}_{-} \mathrm{T}_{3}(1,200 \mu \mathrm{Ci} / \mu \mathrm{g})$ was obtained from Perkin Elmer Life Sciences.
The enzyme immunoassay (EIA) kit for detection of total T3 was purchased from International Immuno-Diagnostics. ISO pellets were obtained from Innovative Research of America. Matrigel and Biocoat Matrigel invasion chambers were from BD Biosciences. Antibodies against vascular endothelial growth factor (VEGF) (SPM 225), synaptophysin (SYP) (H-03), cAMP response element binding protein (CREB-1) (240), pCREB-1 (Ser 133), goat anti-rabbit IgG-horseradish peroxidase (HRP) and goat anti-mouse IgG-HRP were from Santa Cruz Biotechnology. Peroxidase block solution and 3,3'-diaminobenzidine tetrahydrochloride (DAB) were from Dako. Nitrocellulose membranes were from Bio-Rad, and the electrochemiluminescent (ECL) detection system was from GE Healthcare Life Sciences. The VEGF human sandwichenzyme-linked immunosorbent assay (ELISA) kit was from Abcam. All other reagents used in this study were of the highest purity commercially available.

\section{Prostate Cancer Cell Lines}

Cancerous human prostate cells were obtained directly from ATCC. LNCaP cells (CRL-1740, low invasive potential) were derived from a metastasis to lymph node and grown in RPMI-1640 medium supplemented with $10 \%(\mathrm{v} / \mathrm{v})$ fetal bovine serum (FBS). DU145 cells (HTB-81, high invasive potential) were derived from a metastasis to brain and grown in Dulbecco's modified Eagle's medium (DMEM) with $10 \%$ FBS. Both media were supplemented with $100 \mathrm{U} / \mathrm{mL}$ penicillin and $100 \mu \mathrm{g} / \mathrm{mL}$ streptomycin, and cultures were maintained at $37^{\circ} \mathrm{C}$ in a $5 \% \mathrm{CO}_{2}$ atmosphere.

\section{BALB/C Nude Mice and LNCaP Tumor Induction}

Male nude BALB/c mice (Foxn $1^{n u}$ ) were obtained from The Jackson Laboratory and housed in acrylic cages with filtered, pathogen-free air under a controlled temperature $\left(22 \pm 1^{\circ} \mathrm{C}\right)$ and a 12/12-h day-night cycle (lights off at 1800). The animals had free access to rat chow (Purina) and tap water. LNCaP cells $\left(5 \times 10^{6}\right)$ were subcutaneously injected in $100 \mu \mathrm{L}$ Matrigel into the back of 8-wk-old male nude mice. Procedures for handling and euthanasia of mice were reviewed and approved by the Comite de Etica en Investigación from Instituto de Neurobiología, UNAM-Juriquilla (protocol \#014), and complied with guidelines from the Institute of Laboratory Animal Resources Commission on Life Sciences National Research Council, USA (30).

\section{Experimental Design}

Effect of treatments on tumor induction, gene expression and NE differentiation. Two days after xenograft injection, a subset of mice were anesthetized with a mixture of ketamine and xylazine (15 $\mathrm{mg}$ and $3 \mathrm{mg} / \mathrm{kg}$ of body weight, respectively) and implanted in the back with a controlled-release pellet of ISO $(200 \mu \mathrm{g} / \mathrm{d})$. Another group received $\mathrm{T} 3$ in the drinking water $(2.5 \mu \mathrm{g} / \mathrm{d})$, and a third group was cotreated with ISO and T3. All treatments were maintained for $6 \mathrm{wks}$, and five to six animals per group were analyzed. The doses of ISO and the T3 used in this study were based on prior experience showing that they do not compromise the health of the animals $(31,32)$. Body weight, tumor incidence and tumor size were registered every week. Length and width of tumors were measured with a caliper, and the volume was calculated using the ellipsoid formula (33). Mice were sacrificed by decapitation, and blood serum was separated and frozen at $-20^{\circ} \mathrm{C}$ for measurement of circulating T3 levels (radioimmunoassay [RIA]). Prostate tumors were processed for immunohistochemistry and molecular biology (EIA or polymerase chain reaction $[\mathrm{PCR}])$. Tumors were fixed in $10 \%$ neutral buffered formalin to analyze for the presence of proteins related to NE differentiation (SYP) and invasiveness (VEGF). Tumor T3 levels were quantified by EIA, and gene expression was analyzed by real-time PCR. Table 1 shows the oligonucleotides used to analyze genes of the 
Table 1. Oligonucleotides used for real-time PCR.

\begin{tabular}{|c|c|c|c|c|c|}
\hline & Gene & GenBank ID & Sense & Antisense & $\begin{array}{c}\text { Size } \\
\text { (base pairs) }\end{array}$ \\
\hline \multirow{7}{*}{$\begin{array}{l}\text { Thyroid hormone } \\
\text { availability and } \\
\text { action }\end{array}$} & $\beta$-Actin & 001101 & ACAGAGTACTTGCGCTCAGGA & CCATCATGAAGTGTGACGTTG & 185 \\
\hline & $M C T-8$ & 006517 & GCGCTACTTCACCTACGGGA & CAGACACCACACCATTGGC & 125 \\
\hline & D1 & 000792.5 & TTGGGAGTTTATCGAAGGTAATAGG & TGGAACTAAAGTCTTCAATAAGCCTCTT & 165 \\
\hline & D3 & 001362.3 & TGAGACTCCTGGGGAATGAC & CAGCAGCTCGCCTAGGACT & 110 \\
\hline & TR- $\beta 1$ & 001128177 & ATGACTCCCAACAGTATGACAG & TCCAGTCGTGTTCTCGGTCT & 65 \\
\hline & ARA70 & 01145260 & TGCCATTGGTCTTCAGGCTCCT & CAGGCATCGCTGAAGAAACTGC & 124 \\
\hline & $A R$ & 001011645 & GGAATTCCTGTGCATGAAA & CGAAGTTCATCAAAGAATT & 84 \\
\hline \multirow{8}{*}{$\begin{array}{l}\text { NE differentiation } \\
\text { and cell invasion }\end{array}$} & $A D R-\beta 2$ & 000024.5 & GGCAGCTCCAGAAGATTGAC & GTCTTGAGGGCTTTGTGCTT & 139 \\
\hline & VEGF & 001025368 & GGCCTCCGAAACCATGAACTTTCTGCT & ССTCCTGCCCGGCTCACCCGC & 165 \\
\hline & UPA & 01145031.1 & GTGGCCAAAAGACTCTGAGG & CAAGCGTGTCAGCGCTGTAG & 267 \\
\hline & MMP-9 & 04994.2 & TGG TCC TGG TGC TCC TGG TG & GCTGCCTGTCGGTGAGATTGG & 111 \\
\hline & $p 27^{k i p}$ & 004064.3 & ATGTCAAACGTGCGAGTGTC & TCTGTAGTAGAACTCGGGCAA & 262 \\
\hline & Survivin & 01012270.1 & GATTTGAATCGCGGGACCC & GATTTGAATCGCGGGACCC & 64 \\
\hline & $\operatorname{Cg} A$ & 001275.3 & TGAACAGCCCTATGAATAAA & GATGAACTCTCAGAGGTTCTTGAG & 260 \\
\hline & NSE & 001975.2 & TGTGGTGGAGCAAGAGAAACTGGA & TTGGTGGCATCCTTGCCGTATTTG & 345 \\
\hline
\end{tabular}

T3 response, NE differentiation and cell invasion. Most of the T3 response genes contain thyroid response element (TRE) sites, whereas the NE and invasiveness genes contain cAMP response element (CRE) sites.

Effect of treatments on NE differentiation and cell invasion in LNCaP and DU145 cells. LNCaP or DU145 cells $\left(2 \times 10^{4}\right)$ were seeded on 12-well plates in RPMI phenol red-free medium or DMEM, respectively, and both media were supplemented with $5 \%$ charcoal-stripped FBS. LNCaP and DU145 cells were treated for 6 and $4 d$, respectively, with ISO $(50 \mu \mathrm{mol} / \mathrm{L})$, T3 (10 nmol/L), T4 (100 nmol/L), $\mathrm{ISO}+\mathrm{T} 3$ or ISO + T4 . The selected doses and times were based on previous assays $(8,28,34)$. In both cell types, the number and length of neurite-like projections were measured in four random fields of non-clustered cells. The NE-like morphology of the cells was analyzed by phase-contrast microscopy (Olympus IX 50) at 20× magnification. Image analysis was performed using Infinity Capture and Infinity Analyze software, version 6.0 (Lumenera Corporation). VEGF secretion and cell invasion were analyzed as indicators of cancer progression. VEGF was quantified in the culture media by ELISA. Cell invasion was analyzed by Transwell assay by using chambers coated with Matrigel matrix. In brief, $2.5 \times 10^{4} \mathrm{LNCaP}$ or DU145 cells were added to the upper chamber of the Transwell with their respective treatment. The lower chamber was filled with RPMI or DMEM + $10 \%$ FBS as chemoattractant. After $36 \mathrm{~h}$ of incubation, the upper surfaces of the Transwells were wiped, and the inserts were fixed with methanol and stained with $1 \%$ toluidine blue in $1 \%$ borax solution. The number of invading cells was counted by light microscopy (Leica DM 2500, Leica Application Suite, version 2.8.1) in four fields per Transwell assay, by using Image 1.43 u software (National Institutes of Health [NIH]). The effects of treatments on total CREB and pCREB in LNCaP cells were analyzed by immunoblotting. To extract total protein, cells were incubated for $6 \mathrm{~d}$ and then lysed in RIPA buffer and centrifuged at $12,000 \mathrm{~g}$ for $10 \mathrm{~min}$ at $4^{\circ} \mathrm{C}$.

\section{Analytical Methods}

RIA. Circulating levels of T3 were measured by homologous RIA as previously described (35). The assay contained serum or standards (0.1-4.0 ng T3/mL), hypothyroid serum, anti-T3 antibody $(1: 2,000)$ and ${ }^{125} \mathrm{I}-\mathrm{T} 3(0.05 \mathrm{ng} / \mathrm{mL})$ in a final volume of $350 \mu \mathrm{L}$. The incubation time was $24 \mathrm{~h}$ at $4^{\circ} \mathrm{C}$. Bound and free T3 was separated by adding $0.5 \%$ charcoal-dextran and centrifuging at $1,000 \mathrm{~g}$ for $30 \mathrm{~min}$ at $4^{\circ} \mathrm{C}$. Both fractions were measured in a $\gamma$ radiation counter. All samples were measured in duplicate in the same assay. Results are expressed as ng/dL.

EIA. Tumor T3 levels were measured by EIA. The tumors were homogenized in cold methanol containing $1 \mathrm{mmol} / \mathrm{L}$ propylthiouracil for thyronine extraction. Homogenates were centrifuged at $1,500 \mathrm{~g}$ for $10 \mathrm{~min}$ at $4^{\circ} \mathrm{C}$, and supernatants were evaporated at $65^{\circ} \mathrm{C}$. Precipitates were resuspended in $200 \mu \mathrm{L}$ hypothyroid serum and stored at $-20^{\circ} \mathrm{C}$. The assay contained sample or standards ( 0.75 to $10 \mathrm{ng} \mathrm{T} 3 / \mathrm{mL})$ and anti-T3 antibody conjugated to HRP in a final volume of $200 \mu \mathrm{L}$. The incubation time was $1 \mathrm{~h}$ at room temperature. Tetramethylbenzidine was added and, 20 min later, the reaction was stopped with $\mathrm{HCl}$. Absorbance was measured at $450 \mathrm{~nm}$. The results are expressed as ng T3/g tissue.

ELISA. Human VEGF secretion was quantified in cell culture supernatants by ELISA. Biotinylated monoclonal mouse antibody detects the human secreted isoforms VEGF 121 and VEGF 165. The assay contained sample or standards from 8.0 to $6,000 \mathrm{pg} / \mathrm{mL}$ and anti-VEGF antibody conjugated to HRP-streptavidin. Total protein in the culture medium 
was estimated by the Bradford protein assay. Data are expressed as picograms $\mathrm{VEGF} / \mathrm{mg}$ protein.

Real-time PCR. Gene expression was analyzed by real-time PCR. Total RNA was isolated from the tumors by using TRIzol Reagent (Life Technologies). Synthesis of cDNA was performed with $2 \mu \mathrm{g}$ total RNA using the Superscript II system. PCR was performed on the sequence detector system Rotor-Gene 3000 (Corbett Research) using Maxima SYBR green/Rox PCR mix as an indicator for DNA amplification. The reaction was performed with $1 \mu \mathrm{L}$ cDNA template by using 40 cycles of three-step amplification and the gene-specific primers (Table 1). PCR generated only the expected amplicon, which was demonstrated in each case by electrophoresis of the PCR product through a 3\% agarose gel containing ethidium bromide in Tris-acetic acid-EDTA buffer. No PCR products were observed in the absence of template. Relative expression of the genes was calculated by using a standard curve and normalized to $\beta$-actin expression. The coefficient of variation for $\beta$-actin was $<12 \%$ in all conditions.

Immunohistochemistry for SYP and VEGF proteins. Briefly, paraffin tissue sections were deparaffinized and rehydrated. Antigen retrieval was done by adding $0.05 \%$ citraconic anhydride solution, $\mathrm{pH} 7.4$, and heating in a pressure cooker for $25 \mathrm{~min}$. Sections were blocked with peroxidase block solution and then incubated overnight at $4^{\circ} \mathrm{C}$ with anti-SYP or anti-VEGF antibodies (both, 1:100). Slides were then incubated with the secondary antibody (goat anti-rabbit IgG-HRP or goat anti-mouse IgG-HRP [both, $1: 1,000$ ]) at $37^{\circ} \mathrm{C}$ for $1 \mathrm{~h}$. SYP and VEGF proteins were visualized with DAB. Sections were counterstained with hematoxylin, dehydrated and mounted in Entellan ${ }^{\circledR}$ solution. Adrenal tissue was processed and used as positive control. Tissues incubated without primary antibodies were used as negative controls. Images were acquired with a camera (Leica DFC 420) and analyzed under light microscopy (Leica DM 2500) at $100 \times$.

Immunoblotting of CREB and pCREB. Protein extracts ( 25 or $50 \mu \mathrm{g}$ per lane) were resolved through $15 \%$ sodium dodecyl sulfate-polyacrylamide gel electrophoresis (SDS-PAGE) and transferred to nitrocellulose membranes by electroblotting. Membranes were washed with Tris-buffered saline (TBS) (pH 7.5) and blocked with $5 \%$ nonfat milk in TBS + $0.05 \%$ Tween 20 (TBST) for $2 \mathrm{~h}$ at room temperature. Membranes were washed three times with TBST (10 $\mathrm{min}$ ) and incubated overnight at $4^{\circ} \mathrm{C}$ with specific antibodies against CREB or pCREB (both 1:1,000). Membranes were washed three times with TBST (10 min) and then incubated with the goat anti-rabbit IgG-HRP $(1: 5,000)$ for $2 \mathrm{~h}$ at room temperature. Detection was performed using an ECL system. The membranes were analyzed by densitometry using ImageJ $1.43 \mathrm{u}$ software. pCREB levels were normalized to total CREB.

\section{Statistical Analysis}

Data are reported as mean \pm standard error of the mean (SEM). Tumor incidence was analyzed by using a $\chi^{2}$ test. Homogeneity of variances was determined by Bartlett and Brown-Forsythe tests. Data with normal distribution were analyzed using one- or two-way analysis of variance (ANOVA), followed by a Tukey post hoc test. Data with nonparametric distribution were analyzed with a Kruskal-Wallis test followed by a Dunn post hoc test. Values with $p<0.05$ were considered statistically significant. The statistical analysis was performed with GraphPad Prism 6 software (GraphPad Software).

\section{RESULTS}

\section{Body Weight, Incidence and LNCaP Tumor Growth}

Treatments with ISO, T3 or ISO + T3 did not significantly affect the body weight (Figure 1A), but they modified the incidence and growth of tumors (Figures 1B, C). The data show that
$100 \%$ of the control mice treated with ISO or ISO + T3 developed tumors, whereas only $85 \%$ of the T3-treated mice developed them. ISO and ISO + T3 groups showed a tumor latency of 2 wks, whereas in control and T3 groups, the tumors appeared by wk 3. Rapid tumor growth occurred between the fourth and sixth week in the control group (Figure 1C). In contrast, tumors in the T3, ISO and T3 + ISO groups grew more slowly and were smaller at $6 \mathrm{wks}$ of treatment. The lowest growth was observed in the ISO groups (ISO and ISO + T3).
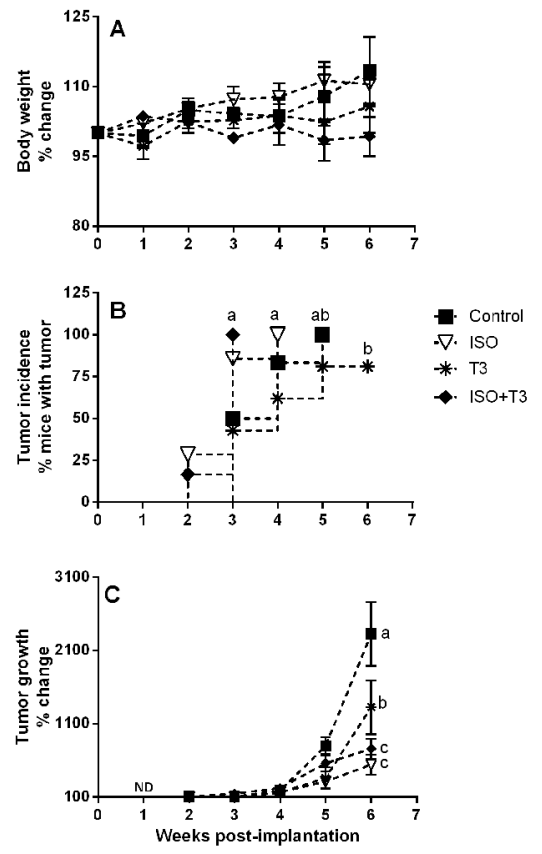

Figure 1. Body weight, tumor incidence and growth. Mice were treated with ISO $(200 \mu \mathrm{g} / \mathrm{d})$, T3 $(2.5 \mu \mathrm{g} / \mathrm{d})$ or both for 6 wks. Body weight (A) and tumor growth (C) are reported as percent change relative to initial weights. Tumor incidence (B) and tumor growth were registered every week. Data are reported as mean \pm SEM. Body weight and tumor growth were analyzed by two-way ANOVA and post hoc Tukey tests. Tumor incidence was analyzed by a $\chi^{2}$ test. Different letters show differences with $p<0.05$. There were no significant differences in body weight. $\mathrm{n}=6$ mice/group. ND, not detectable. 
T3 Levels and Gene Expression Associated with Thyroid Response in LNCaP Tumors

ISO administration did not modify serum and tumor levels of T3, but T3 supplementation increased both parameters by $20-30 \%$, compared with the control group (Figure 2A). Figure $2 \mathrm{~B}$ shows the effects of treatments on the expression of genes associated with the availability and response to T3: monocarboxylate transporter 8 (MCT-8), type 1 deiodinase $(D 1)$, type 3 deiodinase $(D 3)$, thyroid nuclear receptor (TR- $\beta 1)$ and a T3-responsive gene of prostate epithelium, the $\alpha$-spliced isoform of androgen receptor associated protein $70(A R A 70 \alpha)$. In comparison with the control group, ISO significantly reduced D3 expression by $60 \%$, but it did not affect the other genes. T3 treatment increased D1 and $A R A 70 \alpha$ expression by 40 or $50 \%$, but had no effect on the MCT-8 transporter or D3 expression. Compared with the control group, an evident but nonsignificant decrease in $T R-\beta 1(60 \%)$ was observed in response to T3. In the combined group (ISO + $\mathrm{T} 3)$, the low expression of D3 is consistent with the reduction mediated by ISO. On the other hand, ISO antagonized the decrease in TR- $\beta 1$ expression associated with $\mathrm{T} 3$, but it did not antagonize the T3-induced increase of ARA70 $\alpha$.

\section{Gene Expression Associated with NE Differentiation and Cell Invasion in LNCaP Tumors}

Figure 3 shows the expression of typical genes of prostate epithelium (A), NE differentiation (B) and cell invasion (C). ISO doubled or tripled expression of the androgen receptor $(A R)$, survivin, chromogranin A $(C g A)$, neuron-specific enolase (NSE), urokinase plasmin activator $(u P A), V E G F$ and metalloproteinase-9 (MMP-9) genes, and it reduced by three-fold the expression of the $\beta 2$-adrenergic receptor $(A D R-\beta 2)$ compared with the control group. The increase of $p 27^{k i p}$ by ISO was not significant. T3 alone did not modify the basal expression of these genes, but it prevented the up- or downregulation induced by ISO.

Representative images of SYP and VEGF proteins immunodetected in LNCaP tumors are shown in Figure 4. Higher

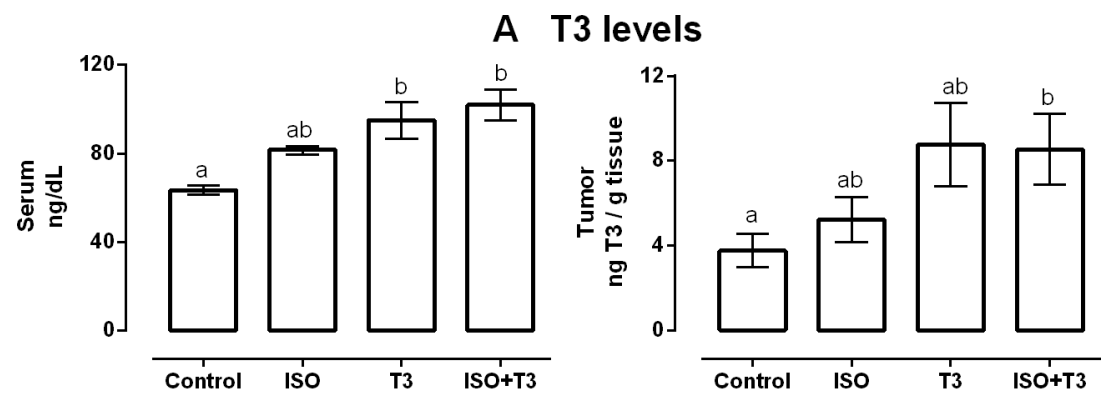

B Gene expression associated with T3 response

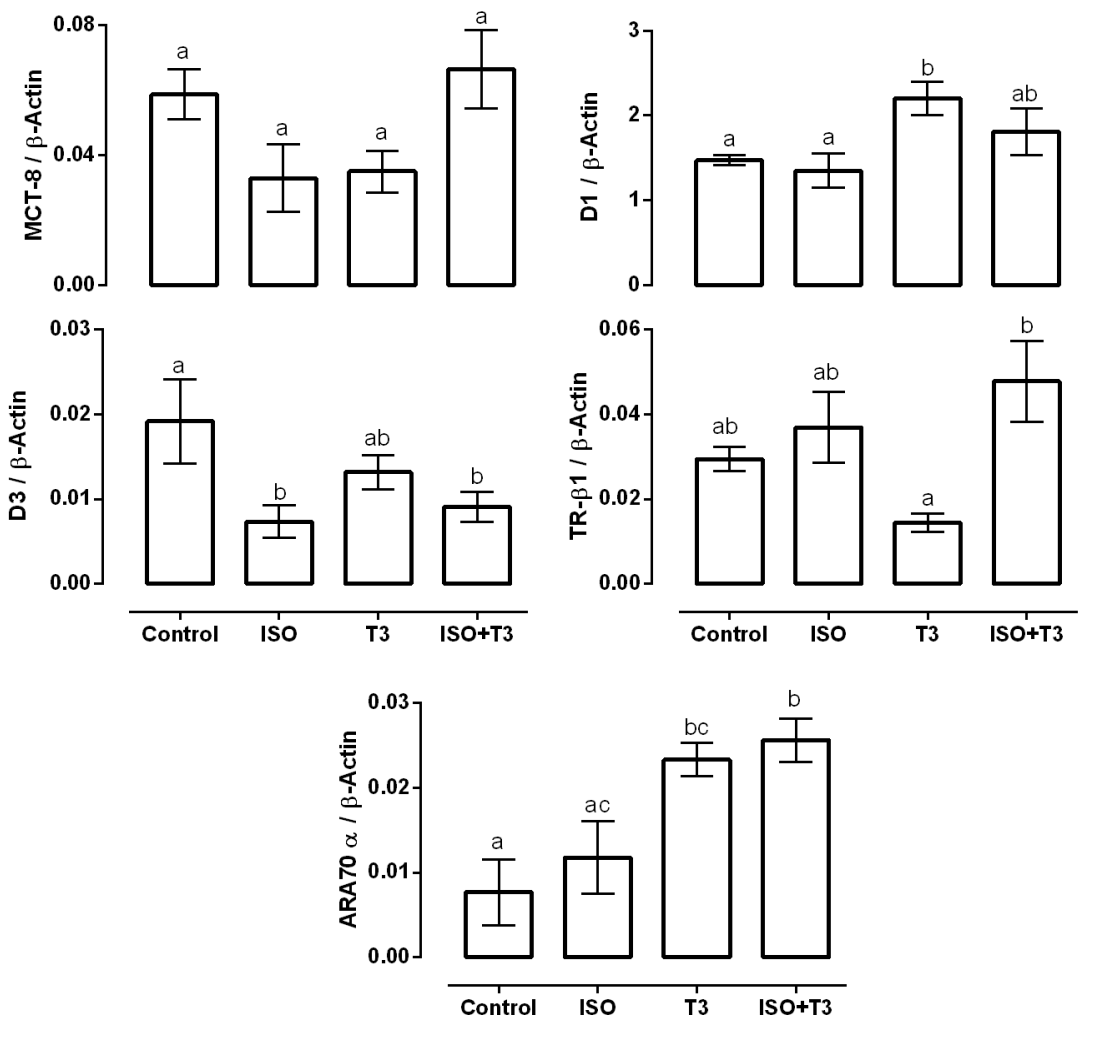

Figure 2. T3 levels and gene expression related to the thyroid response in LNCaP tumors. (A) Serum and tumor levels of T3 were measured by RIA and EIA, respectively. (B) mRNA levels were quantified by real-time PCR. Data are reported as mean \pm SEM. Serum and tumor T3 levels were analyzed by Kruskal-Wallis and post hoc Dunn tests. Gene expression data were analyzed by one-way ANOVA and Tukey post hoc tests. Different letters show differences with $p<0.05$. There were no significant differences in the MCT-8 transporter. $\mathrm{n}=5-6$ samples/group, each analyzed in duplicate. 


\section{Gene expression in LNCaP tumors}

\section{A Prostate epithelium}
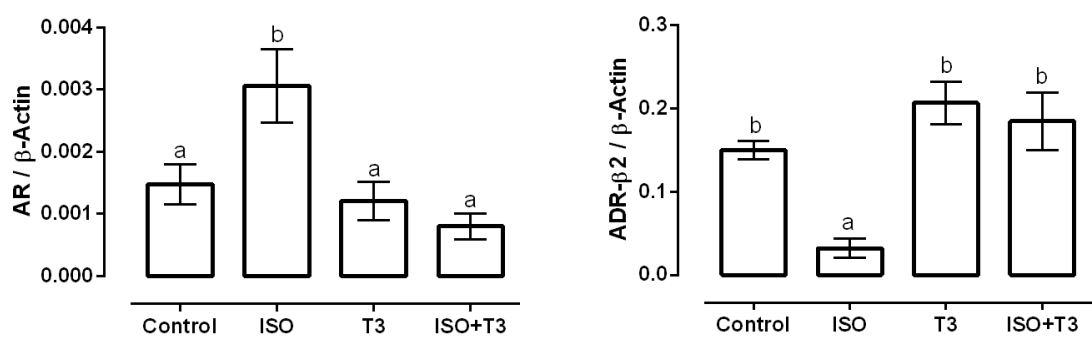

B NE differentiation
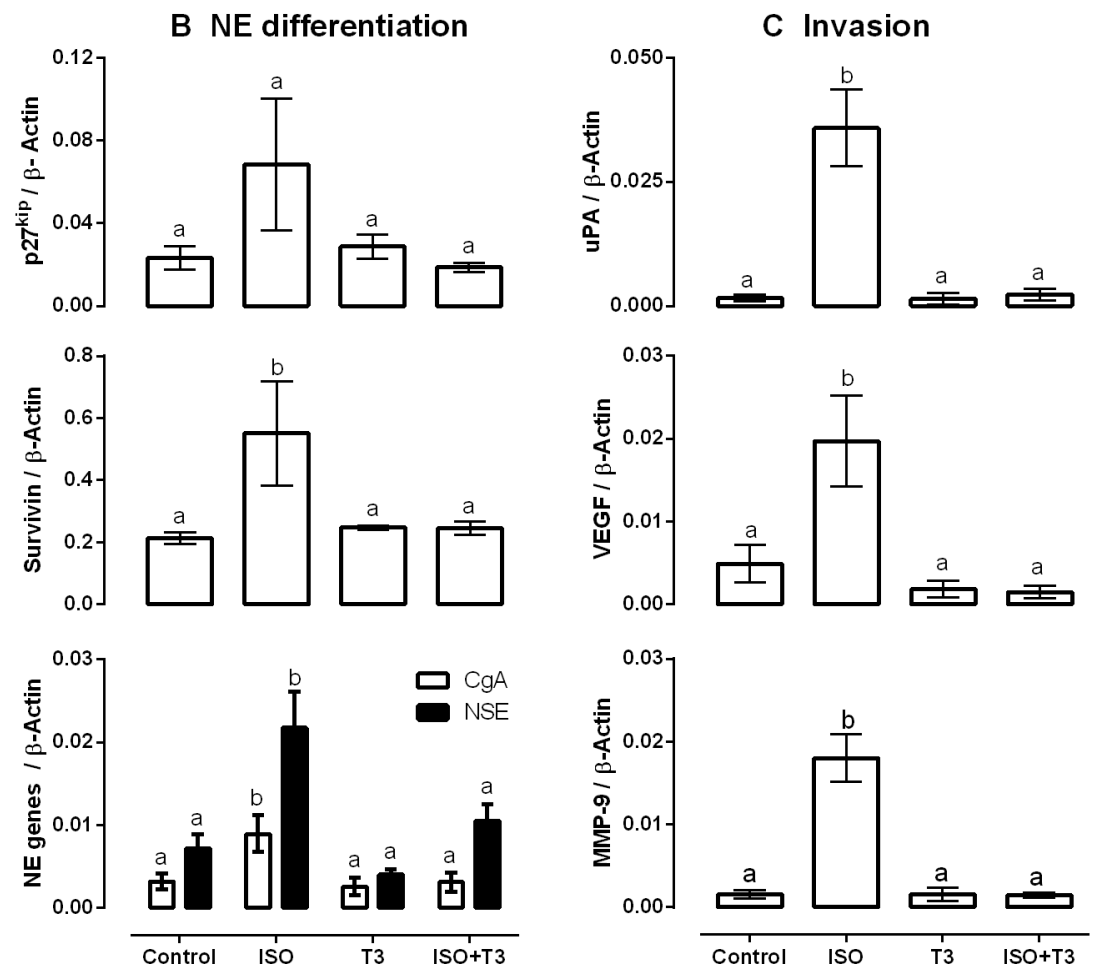

Figure 3. Expression of prostate epithelium (A), NE differentiation (B) and cell invasion (C) in LNCaP tumors. mRNA levels were analyzed by real-time PCR. Data are reported as mean \pm SEM. p2 $7^{k i p}$ was analyzed by Kruskal-Wallis and post hoc Dunn tests, and the rest of the genes were analyzed by one-way ANOVA and post hoc Tukey tests. Different letters show differences with $p<0.05$. There were no significant differences in $p 27^{k i p}$. $\mathrm{n}=5-6$ samples/group, each analyzed in duplicate.

control (adrenal medulla), and no signal was observed in the negative controls.

\section{NE Differentiation and Cell Invasion in Human Prostate Cancer Cell Lines \\ Studies in LNCaP and DU145 cells were carried out to determine if the increases of gene expression and tumor proteins are associated with the}

acquisition of neurite-like projections and invasive properties. We also included a T4-treated group to test the effects of both thyronines on these processes. Figure 5A shows that compared with the control group, ISO consistently increased, by $30-40 \%$, the length and number of neurite-like processes, VEGF secretion and cell invasion in LNCaP cells. T3 itself did not modify any of these parameters, but it prevented the morphological changes and invasive capacity induced by ISO. Similar to ISO, T4 also increased the length and number of neurite-like projections, VEGF secretion, as well as cell invasion. The coadministration of ISO and T4 did not stimulate the acquisition of neurite-like projections or the invasive capacity, but additively stimulated VEGF secretion. In relation to DU145 cells, Figure 5B shows that ISO did not induce the acquisition of neurite-like projections or the invasive capacity, and the apparent increase in VEGF secretion was not significant. None of these parameters were modified by T3 or T4, but a nonsignificant decrease in VEGF secretion was observed in the ISO + T4 group compared with the ISO group.

Levels of total and phosphorylated CREB proteins were evaluated as a first approach to analyze the mechanism by which T3 reduces ISO-stimulated invasiveness in LNCaP cells. Figure 5C shows an evident but nonsignificant increase in the $\mathrm{PCREB} / \mathrm{CREB}$ ratio by ISO and ISO + T3, in comparison with the control or T3 group.

\section{DISCUSSION}

This study supports the notion that sustained $\beta$-adrenergic activation promotes the tumorigenic process (induction of NE differentiation and cell invasion), and it shows that T3 but not T4 attenuates prostate cancer progression.

In nude mice engrafted with $\mathrm{LNCaP}$ cells, ISO-induced $\beta$-adrenergic activation reduced tumor growth but accelerated the latency and incidence of tumors. These data were not surprising, since robust studies show that sympathetic input (via $\beta$-adrenergic receptors) is crucial for the initiation and progression of prostate and hepatic cancer $(12,36,37)$. The decrease in tumor growth by ISO was associated with an increased expression of genes related to cell arrest $\left(p 27^{k i p}\right), \mathrm{NE}$ differentiation (survivin, $C g A$ and NSE) and cell invasion (VEGF, $U P A$ and MMP9) (8,38-43). With the exception of VEGF and survivin, all these genes contain 
Immunohistochemistry in LNCaP tumors

A SYP
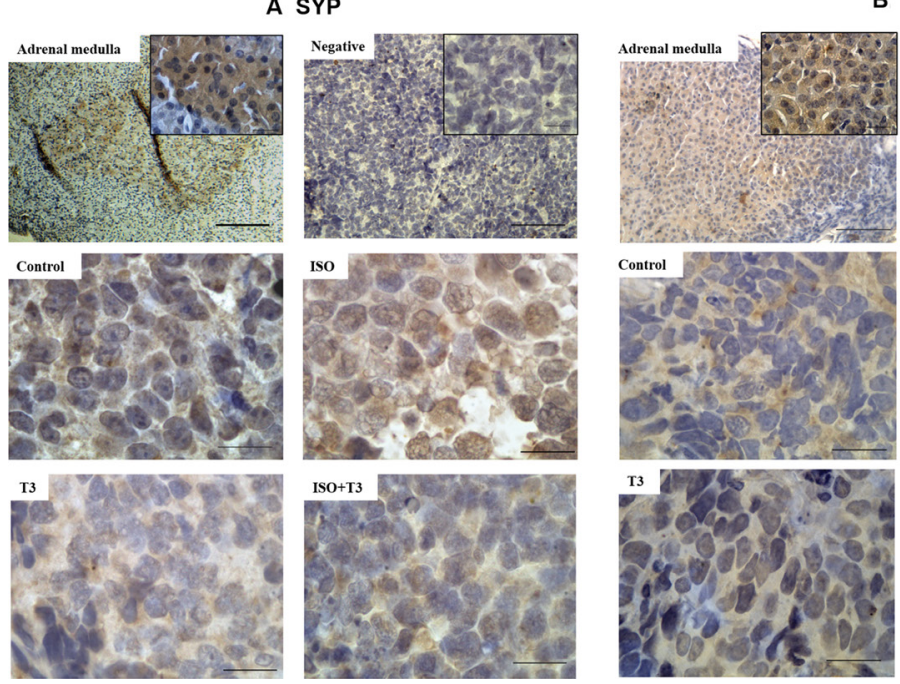

B VEGF

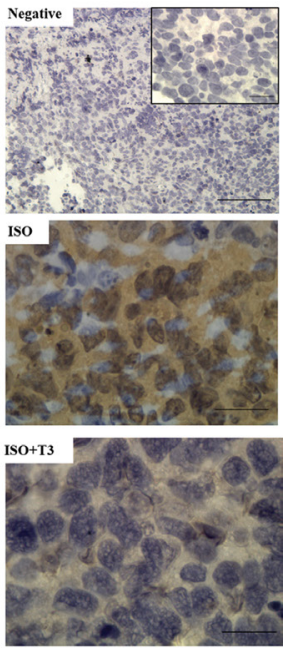

Figure 4. Immunodetection of SYP and VEGF proteins in LNCaP tumors. Representative light microscopy micrographs show immunostaining for SYP (A) and VEGF (B) at 100x magnification. Cell nuclei were counterstained with hematoxylin. Adrenal medulla was used as a positive control for both markers, and a tumor xenograft incubated with PBS instead of primary antibody was used as negative control. Insets, 20x magnification. Scale bars, $20 \mu \mathrm{m}$.

CRE sites (40,42,44-46), suggesting a direct regulation by the transcription factor pCREB. In addition to gene expression, our data indicated high protein levels of SYP (another marker of NE differentiation) and VEGF in ISO-stimulated prostate tumors. These findings correlate with our in vitro data. Acquisition of neurite-like projections, VEGF secretion and invasive potential were consistently increased in ISO-treated LNCaP cultures. The dual effects of ISO are decreased tumor growth and increased invasive capacity; these effects are consistent with the evidence that adrenaline or noradrenaline act by $\beta$-adrenergic mechanisms to reduce cell proliferation but promote acquisition of the NE phenotype and/or invasiveness in prostate cancer cells $(8,11)$. Together, our data support the notion that $\beta$-adrenergic activation promotes prostate cancer progression through increasing NE differentiation and invasive potential $(8,11)$. Mechanistically, it has been established that PKA activation and/or exchange protein activated by cAMP (EPAC) are crucial processes for NE differentiation (47). PKA directly induces the inactivation of an apoptotic factor (phosphorylation of BAD) (9), and it indirectly stimulates VEGF secretion (PI3K/AKT/hypoxia inducible factor- $1 \alpha$ [HIF-1 $\alpha]$ ) (48) and neurite outgrowth by cytoskeleton rearrangements (inhibition of Ras homolog gene family A [RhoA]/Rho-associated protein kinase [ROCK]) (49). PKA also induces the phosphorylation of CREB and the expression of cell survival factors (Bcl-2), metalloproteases and NE peptides (NSE, CgA, SYP, neurotensin and so on) $(8,9,36)$. Along this line, our data confirm an association between acquisition of the NE phenotype and high levels of pCREB in ISO-treated LNCaP cells. We did not analyze EPAC/p38-MAP kinase activation, but it is known that this intermediate effector is related to cell arrest in pheochromocytoma cells (47).

Our data indicate that responsiveness to $\beta$-adrenergic stimulation may depend on the state of differentiation and/or invasive potential of the prostate cancer cells. Compared to LNCaP cells, the highly invasive DU145 cells were less sensitive to $\beta$-adrenergic stimulation; ISO increased VEGF secretion but not the outgrowth of neurites or the invasive capacity. In agreement, a study showed that stimulation with dibutyryl-cAMP or activators of PKA does not, by itself, promotes NE differentiation; instead, it increases the efficiency of epidermal growth factor in inducing the NE phenotype (50). However, this low responsiveness contrasts with other studies showing that $\beta$-adrenergic activation increases or reduces the invasive capacity in DU145 cells. It has been reported that treatment with $10 \mu \mathrm{mol} / \mathrm{L}$ norepinephrine (in the presence of $10 \mu \mathrm{mol} / \mathrm{L}$ propanolol) stimulates cell migration and epithelial-mesenchymal transition (51), whereas in another study, stimulation with $100 \mu \mathrm{mol} / \mathrm{L}$ ISO reduced cell motility by $50 \%$ (52). These differences could not be explained by the dose and/or time of exposure to $\beta$-agonists, and it is evident that more studies are required to understand the effect of $\beta$-adrenergic receptors on the invasiveness of DU145 cells. It is interesting to note that, unlike $\beta$-adrenergic signaling, other signals such as androgen deprivation (PI3K/AKT/MAPK) (53), cytokines (PI3K/signal transducer and activation of transcription [STAT]) (54) and growth factors induce NE differentiation, not only in prostate cancer cells with low invasive potential, but also with high invasive potential $(55,56)$.

In relation to $\mathrm{T} 3$, our models showed that T3 supplementation reduced tumor growth and either up- or downregulated the expression of genes associated with the thyroid response. In contrast, T3 had no effect on tumor incidence, basal expression of CRE-dependent genes, acquisition of NE phenotype or invasiveness. T3 supplementation increased $D 1$ and $A R A 70 \alpha$ mRNA levels and decreased TR- $\beta 1$ mRNA levels. This result is not surprising, since these genes contain TRE sequences in their regulatory regions (57-59). The high levels of D1 expression induced by $\mathrm{T} 3$ are consistent with the positive feedback loop of the 
A LNCaP
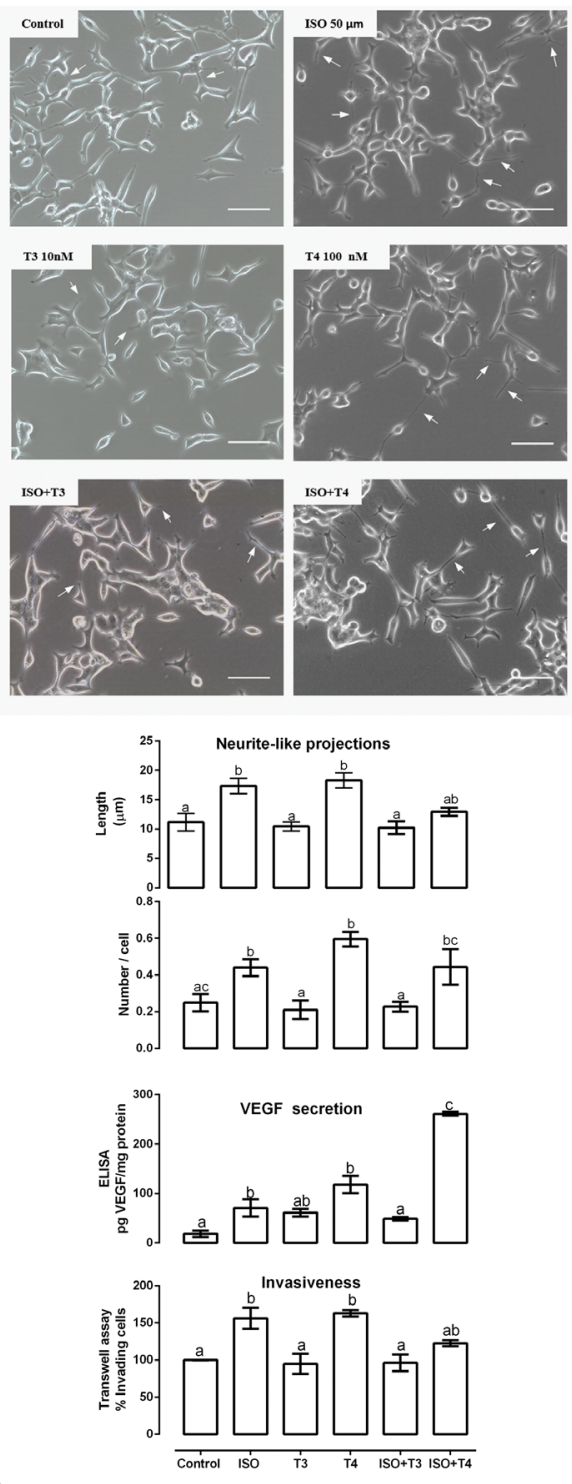

C

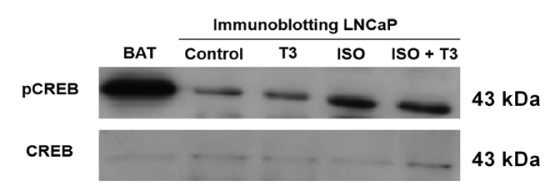

B DU145
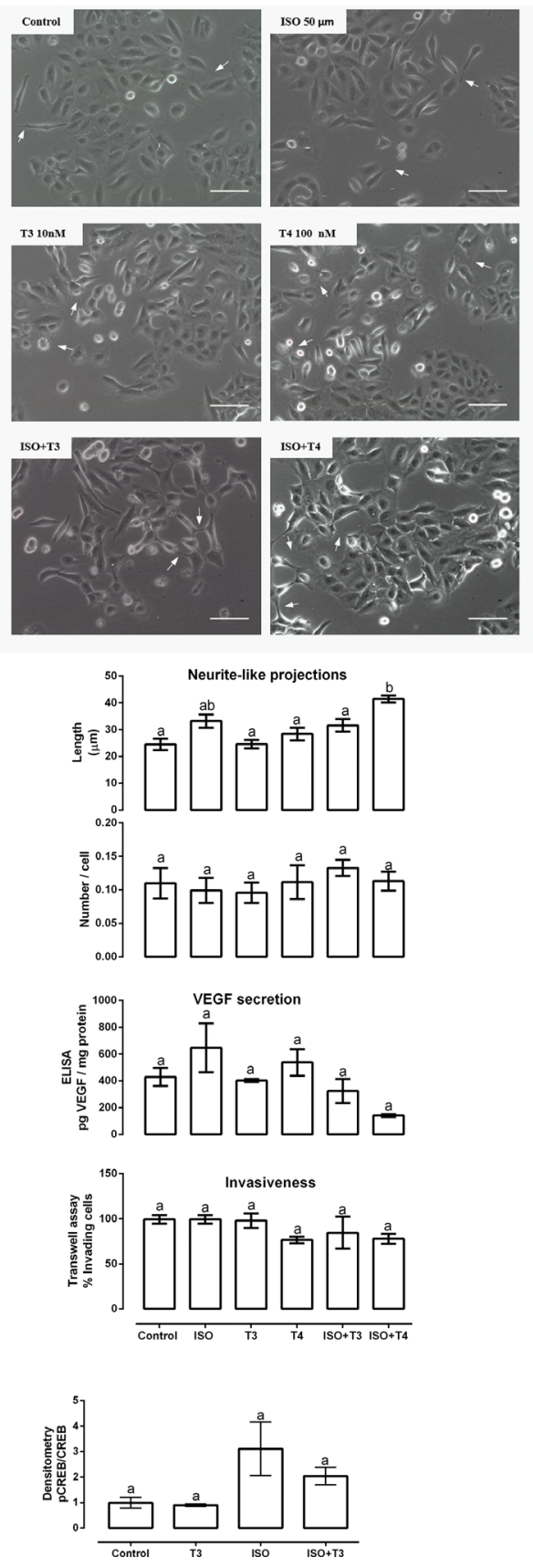

Figure 5. NE phenotype, VEGF secretion and invasive capacity of LNCaP (A) and DU145 cells (B). Cells were treated for $6 \mathrm{~d}$ (LNCaP) or $4 \mathrm{~d}$ (DU145), with $50 \mu \mathrm{mol} / \mathrm{L} \mathrm{ISO}, 10 \mathrm{nmol} / \mathrm{L}$ T3 or $100 \mathrm{nmol} / \mathrm{L}$ T4 and their respective combination with ISO. (A) Representative images by phase contrast microscope at 20x showing the presence of neurite-like projections (see arrows). Scale bar, $50 \mu \mathrm{m}$. (C) Representative immunoblot of PCREB and CREB and densitometric quantification in LNCaP cells. Brown adipose tissue (BAT) of cold-exposed rats was used as a positive control for PCREB. All data represent mean $\pm \mathrm{SEM}$ and were analyzed by one-way ANOVA and post hoc Tukey tests. Different letters indicate differences with $p<0.05 . n=3-5$ independent experiments.

thyroid response (60). Tumor D1 activity was not measured, but previous studies have shown a direct correlation between enzyme activity (deiodination) and T3 generation in normal prostate tissue (35). T3 supplements also increased the expression of $A R A 70 \alpha$, a prostate epithelium T3-responsive gene; ARA70 is reduced in prostate cancer cells, but its overexpression induces apoptosis and reduces the cell-invasive capacity (61). Our data do not allow us to identify a potential role for T3 in the function of ARA70, but there is evidence that ARA70 $\alpha$ might inhibit T3 signaling (58). D1, the other TRE-dependent gene, was not inhibited by ARA70. Studies are necessary to understand the bidirectional effects of T3 and ARA70. The reduced tumor growth associated with T3 could be explained by indirect mechanisms, because in vitro studies show that T3 directly increases cell proliferation by decreasing the expression of a p53 target, the B-cell translocation protein $(28,62)$. Additional studies are required to understand the direct or indirect effects of T3 on tumor prostate growth.

In contrast to the lack of $\mathrm{T} 3$ effects on invasiveness, T4 promoted neurite outgrowth, VEGF secretion and the invasive capacity of LNCaP cells. Although the signaling pathways of T4 were not analyzed in this study, it is highly probable that activation of the $\alpha v \beta 3$ integrin/ MAPK pathway mediates the extension and proliferation of neurites, on the basis of the following evidence: (a) T4 activates the MAPK pathway by interacting with the $\alpha v \beta 3$-integrin receptor (63);

(b) $10 \mathrm{nmol} / \mathrm{L} \mathrm{T} 4$, but not $10 \mathrm{nmol} / \mathrm{L} \mathrm{T3}$, induces the elongation of neurites in cerebellar neurons by activating integrin receptors (64); and (c) MAPK activation is required for neurite outgrowth in pheochromocytoma cells (65). In addition, increased VEGF secretion and invasiveness was observed in T4-treated LNCaP cells. A study in glioma cells showed that $100 \mathrm{nmol} / \mathrm{L}$ T4 increased mRNA HIF- $\alpha 1$ levels (inductor of VEGF) by an interaction with the $\alpha v \beta 3 / \mathrm{Src} / \mathrm{PI}$ K pathway (20). Our data agree with this finding and 
suggest that non-genomic mechanisms could be involved in these $\mathrm{T} 4$ responses.

Our data show that neither T4 nor T3 had effects on neurite outgrowth, VEGF secretion or the invasiveness of DU145 cells; nevertheless, these cells also express the integrin receptor subunits $\alpha v$ and $\beta 3$ (66). Detailed studies are required to analyze the functionality of the $\alpha v \beta 3$ receptor/signaling pathway in these cells. For instance, it has been reported that integrin $\alpha \nu \beta 3$ recycling (mediated by protein kinase D) is crucial for endothelial cell migration (67), and an alteration at this level could explain the unresponsiveness in DU145 cells. Together, our data indicate that the differential effects of thyronines seem to depend on the state of differentiation and/or the invasiveness of cancer cells.

One of the most important findings of this work is that $\mathrm{T} 3$, but not $\mathrm{T} 4$, prevented the tumorigenic progression mediated by $\beta$-adrenergic stimulation in LNCaP cells. As mentioned before, T3 treatment did not modify the basal expression of CRE-dependent genes, but it prevented the upregulation stimulated by ISO. In the combined group, T3 impeded the increases of tumor proteins SYP and VEGF; and in vitro, T3 prevented VEGF secretion, neurite-like outgrowth and invasive capacity. It is well established that T3 acts synergistically with $\beta$-adrenergic pathways to upregulate genes that contain both CRE and TRE sites $(68,69)$, but there is also evidence that T3 represses the expression of genes that have only CRE sites $(29,70,71)$. The lack of TRE sites on genes associated with NE differentiation and cell invasion can explain the null effect of T3 on the basal expression of these genes, suggesting that T3 acts indirectly in the ISO response. Studies have demonstrated a protein-protein interaction between nuclear thyroid hormone receptors and CREB in the presence of T3 (a T3-TR-CREB complex), reducing the ability of PKA to phosphorylate CREB $(29,70)$. In our study, T3 did not fully prevent the phosphorylation of CREB, suggesting that the antagonistic effect of T3 on the $\beta$-adrenergic pathway does not necessarily occur primordially at this level. For instance, in myocytes, T3 inhibits the expression of the L-type calcium channel gene, thereby inhibiting the nuclear translocation of PCREB (71). Another possibility is that T3 inhibits other downstream effectors of the $\beta$-adrenergic pathway associated with tumor progression, such as EPAC, erythroid transcription factor (GATA1) or activator-protein 1 (AP1) (72). Ongoing studies by our group are analyzing the antagonist effect of T3 on the $\beta$-adrenergic pathway. Neither T3 alone nor T3 combined with ISO had any effect on the tumorogenic response of DU145 cells. As mentioned before, this unresponsiveness could be related to the dedifferentiated state and/or the invasive capacity of these cells. TR $\beta 1$, the nuclear thyroid receptor, has been identified in both LNCaP and DU145 cells (29); however, $\mathrm{T} 3$ exerts proliferative effects only in LNCaP cells $(27,62)$. Overall, our data in vitro and in vivo indicate that $\mathrm{T} 3$ restrains cancer progression mediated by $\beta$-adrenergic receptors in a model of differentiated cancer. T4 exacerbated the protumorogenic effects of ISO (VEGF secretion) in $\mathrm{LNCaP}$ cells, but did not have any effect on DU145 cells. Possible crosstalk between $\beta$-adrenergic signaling and T4-induced activation of MAPK could explain this overresponse in LNCaP cells; however, this relationship seems to be complex and is not yet clear. Clinical and experimental studies have shown that chronic systolic and/or diastolic hypertension, which are associated with a high mortality risk in prostate cancer, are also accompanied by lower levels of free T4 and T3 $(2,73,74)$. Antagonistic T3 effects on $\beta$-adrenergic signaling are consistent with the notion that synergism is lost when one of these systems is enhanced or depressed; nevertheless, meticulous studies are needed to analyze if changes in the ratio of $\mathrm{T} 4 / \mathrm{T} 3$ could be relevant for prostate cancer progression. Indeed, epidemiological data suggest that higher T4 levels increase the risk of prostate cancer (75), and our study shows that a moderate and continuous dose of T3, but not T4, might prevent or delay tumor progression in a condition of adrenergic hyperactivity. Moreover, basic and clinical studies support the proposal that emotional, behavioral and surgical stresses, which depress the thyroid axes, accelerate prostate cancer progression $(76,77)$. Oncologists should consider this fact, because the failure of some therapies could be related to the high anxiety levels of cancer patients. It would be interesting to analyze if a moderate dose of $\mathrm{T} 3$ given to prostate cancer patients could counteract the high central sympathetic input associated with hypothyroidism and whether this supplement might improve the efficacy of antineoplastic treatments. Indeed, a study found that pretreatment with supraphysiological doses of T3 enhances the effectiveness of chemotherapy in breast cancer cells (78).

\section{CONCLUSION}

Our study made consistent and complementary findings in $\mathrm{LNCaP}$ tumors and LNCaP cultures. We showed that the $\beta$-adrenergic pathway and thyroid hormones exert differential effects, stimulating or inhibiting prostate cancer progression. The protective effects of T3 against acquisition of the NE phenotype and cell invasion induced by $\beta$-adrenergic activation are associated with a pCREB-independent mechanism. Further studies are required to analyze the possible significance of the T4/T3 ratio for predicting prostatic cancer development.

\section{ACKNOWLEDGMENTS}

This work was supported by CONACYT (127368, 235961, 176911) and PAPIIT-UNAM (202513, 200813). E Delgado-González is a student from the Programa de Doctorado en Ciencias Biomédicas de la Universidad Nacional Autónoma de México and received a fellowship from CONACYT (202474) and PAPIIT (202513). AA Sánchez-Tusie received a postdoctoral fellowship from CONACYT (235961). The authors thank 
María Juana Cárdenas, Martín García and Alejandra Castilla for their technical assistance; Erika Rendón and Berenice Salas (FM-UNAM) for their advice on the cell migration assays; Ramón Martínez, Omar González and Sandra Hernández for computer assistance; Francisco Valles for bibliographical assistance, Leonor Casanova and Lourdes Lara for academic support; and Dorothy Pless for proofreading.

\section{DISCLOSURE}

The authors declare that they have no competing interests as defined by Molecular Medicine, or other interests that might be perceived to influence the results and discussion reported in this paper.

\section{REFERENCES}

1. Center MM, et al. (2012) International variation in prostate cancer incidence and mortality rates. Eur. Urol. 61:1079-92.

2. Gann PH, Daviglus ML, Dyer AR, Stamler J. (1995) Heart rate and prostate cancer mortality: results of a prospective analysis. Cancer Epidemiol. Biomarkers Prev. 4:611-6.

3. Lu H, et al. (2015) Impact of beta-blockers on prostate cancer mortality: a meta-analysis of 16,825 patients. Onco. Targets Ther. 8:985-990.

4. Harris AM, et al. (2007) Effect of alpha1-adrenoceptor antagonist exposure on prostate cancer incidence: an observational cohort study. J. Urol. 178:2176-80.

5. Rao J, et al. (2008) Hypothetic association between greater sympathetic activity and prostate cancer. Med. Hypotheses. 71:442-3.

6. Ganesh B, Saoba SL, Sarade MN, Pinjari SV. (2011) Risk factors for prostate cancer: a hospital-based case-control study from Mumbai, India. Indian J. Urol. 27:345-50.

7. Grytli HH, Fagerland MW, Fosså SD, Taskén KA. (2014) Association between use of $\beta$-blockers and prostate cancer-specific survival: a cohort study of 3561 prostate cancer patients with high-risk or metastatic disease. Eur. Urol. 65:635-41.

8. Cox ME, Deeble PD, Lakhani S, Parsons SJ. (1999) Acquisition of neuroendocrine characteristics by prostate tumor cells is reversible: implications for prostate cancer progression. Cancer Res. 59:3821-30.

9. Sastry KR, et al. (2007) Epinephrine protects cancer cells from apoptosis via activation of cAMP-dependent protein kinase and BAD phosphorylation. J. Biol. Chem. 282:14094-100.

10. Zhang P, He X, Tan J, Zhou X, Zou L. (2011) $\beta$-Arrestin2 mediates $\beta$ - 2 adrenergic receptor signaling inducing prostate cancer cell progression. Oncol. Rep. 26:1471-7.
11. Palm D, et al. (2005) The norepinephrine driven metastasis development of PC-3 human prostate cancer cells in BALB/c nude mice is inhibited by $\beta$-blockers. Int. J. Cancer. 118:2744-9.

12. Magnon C, et al. (2013) Autonomic nerve development contributes to prostate cancer progression. Science. 341:123361.

13. Bonkhoff H, Stein U, Remberger K. (1995) Endocrine-paracrine cell types in the prostate and prostatic adenocarcinoma are postmitotic cells. Hum. Pathol. 26:167-70.

14. Grigore AD, Ben-Jacob E, Farach-Carson MC (2015) Prostate cancer and neuroendocrine differentiation: more neuronal, less endocrine? Front. Oncol. 5:37.

15. Ramberg H, et al. (2008) Hormonal regulation of beta-2 adrenergic receptor level in prostate cancer. Prostate. 68:1133-42.

16. Hassan S, et al. (2014) A pilot study of blood epinephrine levels and CREB phosphorylation in men undergoing prostate biopsies. Int. Urol. Nephrol. 46:505-10.

17. di Sant'Agnese PA. (1992) Neuroendocrine differentiation in carcinoma of the prostate: diagnostic, prognostic, and therapeutic implications. Cancer. 70:254-68.

18. Papandreou CN, et al. (2002) Results of a phase II study with doxorubicin, etoposide, and cisplatin in patients with fully characterized small-cell carcinoma of the prostate. J. Clin. Oncol. 20:3072-80.

19. Moriggi G, et al. (2011) Thyroid hormones (T3 and T4): dual effect on human cancer cell proliferation. Anticancer Res. 31:89-96.

20. Lin HY, et al. (2009) L-Thyroxine vs. 3,5,3'-triiodo-L-thyronine and cell proliferation: activation of mitogen-activated protein kinase and phosphatidylinositol 3-kinase. Am. J. Physiol. Cell Physiol. 296:C980-1.

21. Pinto M, Soares P, Ribatti D. (2011) Thyroid hormone as a regulator of tumor induced angiogenesis. Cancer Lett. 301:119-26

22. Mousa SA, O'Connor L, Davis FB, Davis PJ. (2006) Proangiogenesis actions of the thyroid hormone analog 3,5-diiodothyropropionic acid (DITPA) is initiated at the cell surface and is integrin mediated. Endocrinology. 147:2602-7.

23. Perez-Juste G, Aranda A. (1999) The cyclindependent kinase inhibitor p27(Kip1) is involved in thyroid hormone-mediated neuronal differentiation. J. Biol. Chem. 274:5026-31.

24. Sar P, Peter R, Rath B, Mohapatra AD, Mishra SK. (2011) 3,3'5 Triiodo L thyronine induces apoptosis in human breast cancer MCF-7 cells, repressing SMP30 expression through negative thyroid response elements. PLoS One. 6:e20861.

25. Perra A, Kowalik MA, Pibiri M, Ledda-Columbano GM, Columbano A. (2009) Thyroid hormone receptor ligands induce regression of rat preneoplastic liver lesions causing their reversion to a differentiated phenotype. Hepathology. 49:1287-96.

26. Zhang $S$, et al. (1999) Interactive effects of triiodothyronine and androgens on prostate cell growth and gene expression. Endocrinology. 140:1665-71.
27. Hsieh ML, Juang HH. (2005) Cell growth effects of triiodothyronine and expression of thyroid hormone receptor in prostate carcinoma cells. J. Androl. 26:422-8.

28. Tsui KH, Hsieh WC, Lin MH, Chang PL, Juang HH. (2008) Triiodothyronine modulates cell proliferation of human prostatic carcinoma cells by downregulation of the B-cell translocation gene 2. Prostate. 68:610-9.

29. Fukuyama K, et al. (2006) Thyroid hormone inhibits vascular remodeling through suppression of cAMP response element binding protein activity. Arterioscler. Thromb. Vasc. Biol. 26:2049-55.

30. Institute of Laboratory Animal Resources, Commission on Life Sciences, National Research Council. (1999) Guía para el Cuidado y Uso de los Animales de Laboratorio. Edicion Mexicana auspiciada por la Academia Nacional De Medicina. National Academy Press, Washington (DC). English version, 1996. Available from: http://www.conicyt.cl/fondecyt/files/2012/10/Gu\%C3\%ADa-para-el-Cuidado-y-Uso-de-los-Animales-de-Laboratorio.pdf.

31. Berthonneche C, et al. (2009) Cardiovascular response to beta-adrenergic blockade or activation in 23 inbred mouse strains. PLoS One. 4:e6610.

32. Henderson KK, et al. (2009) Physiological replacement of T3 improves left ventricular function in an animal model of myocardial infarction-induced congestive heart failure. Circ. Heart Fail. 2:243-52.

33. Thompson HJ. (2000) Methods for the induction of mammary carcinogenesis in the rat using either 7,12-dimethylbenz $(\alpha)$ antracene or 1-methyl-1-nitrosourea. In: Methods in Mammary Gland Biology and Breast Cancer Research. Ip MM, Asch BB (eds.) Klumer Academic/Plenum Publishers, New York, pp. 19-29.

34. Incerpi S, et al. (2014) Thyroid hormone inhibition in L6 myoblasts of IGF-I-mediated glucose uptake and proliferation: new roles for integrin avß3. Am. J. Physiol. Cell Physiol. 307:C150-61.

35. Delgado-Gonzalez E, Aceves C, Anguiano B. (2011) Postejaculatory increase of prostatic triiodothyronine (T3) depends on sympathetic innervation in the rat. Biol. Reprod. 84:118-23.

36. Braadland PR, Ramberg H, Grytli HH, Taskén KA. (2015) B-adrenergic receptor signaling in prostate cancer. Front. Oncol. 4:375.

37. Uehara H, Nakaizumi A, Baba M, Iishi H, Tatsuta M. (1993) Enhancement by isoproterenol of hepatocarcinogenesis induced by $\mathrm{N}$-nitrosomorpholine in Sprague-Dawley rats. Int. J. Cancer. 53:703-6.

38. Pinski J, et al. (2006) Genistein-induced neuroendocrine differentiation of prostate cancer cells. Prostate. 66:1136-43.

39. Xing N, Qian J, Bostwick D, Bergstralh E, Young CY. (2001) Neuroendocrine cells in human prostate over-express the anti-apoptosis protein survivin. Prostate. 48:7-15.

40. Canaff L, et al. (1998) Analysis of molecular mechanisms controlling neuroendocrine cell specific transcription of the chromogranin A gene. Endocrinology. 139:1184-96. 
41. Lutgendorf S, et al. (2003) Stress-related mediators stimulate vascular endothelial growth factor secretion by two ovarian cancer cell lines. Clin. Cancer Res. 9:4514-21.

42. Yang EV, et al. (2006) Norepinephrine up-regulates the expression of vascular endothelial growth factor, matrix metalloprotease (MMP)-2, and MMP-9 in nasopharyngeal carcinoma tumour cells. Cancer Res. 66:10357-64.

43. Guo K, et al. (2009) Norepinephrine induced invasion by pancreatic cancer cells is inhibited by propanolol. Oncol. Rep. 22:825-30.

44. Kwon TK, Nagel JE, Buchholz MA, Nordin AA. (1996) Characterization of the murine cyclin dependent kinase inhibitor p27 $7^{\mathrm{kip} 1}$. Gene. 180:113-20.

45. Oliva D, Calì L, Feo S, Giallongo A. (1991) Complete structure of the human gene encoding neuron-specific enolase. Genomics. 10:157-65.

46. von der Ahe D, Pearson D, Nagamine Y. (1990) Macromolecular interaction on a AMP responsive region in the urokinase plasmin activator gene: a role of protein phosphorylation. Nucleic Acids Res. 18:1991-9.

47. Emery AC, Eiden MV, Eiden LE. (2014) Separate cyclic AMP sensors for neuritogenesis, growth arrest, and survival of neuroendocrine cells. J. Biol. Chem. 289:10126-39.

48. Park SY, et al. (2011) Norepinephrine induces VEGF expression and angiogenesis by a hypoxiainducible factor- 1 alpha protein-dependent mechanism. Int. J. Cancer. 128:2306-16.

49. Jones SE, Palmer TM. (2012) Protein kinase A-mediated phosphorylation of RhoA on serine 188 triggers the rapid induction of a neuroendocrine-like phenotype in prostate cancer epithelial cells. Cell. Signal. 24:1504-14.

50. Humez S, et al. (2006) Epidermal growth factor-induced neuroendocrine differentiation and apoptotic resistance of androgen-independent human prostate cancer cells. Endocr. Relat. Cancer. 13:181-95.

51. Barbieri A, et al. (2015) The stress hormone norepinephrine increases migration of prostate cancer cells in vitro and in vivo. Int. J. Oncol. 47:527-34.

52. Yu J, et al. (2007) Integrative genomics analysis reveals silencing of beta-adrenergic signaling by polycomb in prostate cancer. Cancer Cell. 12:419-31.

53. Murillo H, Huang H, Schmidt LJ, Smith DI, Tindall DJ. (2001) Role of PI3K signaling in survival and progression of LNCaP prostate cancer cells to the androgen refractory state. Endocrinology. 142:4795-805.

54. Deeble PD, Murphy DJ, Parsons SJ, Cox ME. (2001) Interleukin-6- and cyclic AMP-mediated signaling potentiates neuroendocrine differentiation of $\mathrm{LNCaP}$ prostate tumor cells. Mol. Cell. Biol. 21:8471-82.

55. Marchiani S, et al. (2010) Androgen-responsive and -unresponsive prostate cancer cell lines respond differently to stimuli inducing neuroendocrine differentiation. Int. J. Androl. 33:784-93.
56. Mori R, et al. (2009) Gene profiling and pathway analysis of neuroendocrine transdifferentiated prostate cancer cells. Prostate. 69:12-23.

57. Zhang CY, Kim S, Harney JW, Larsen PR. (1998) Further characterization of thyroid hormone response elements in the human type 1 iodothyronine deiodinase gene. Endocrinology. 39:1156-63.

58. Tai PJ, et al. (2007) Direct regulation of androgen receptor associated protein 70 by thyroid hormone and its receptors. Endocrinology. 148:3485-95.

59. Suzuki S, Miyamoto T, Opsahl A, Sakurai A, DeGroot LJ. (1994) Two thyroid hormone response elements are present in the promoter of human thyroid hormone receptor beta $1 . \mathrm{Mol}$. Endocrinol. 8:305-14.

60. Gereben B, et al. (2008) Cellular and molecular basis of deiodinase-regulated thyroid hormone signaling. Endocr. Rev. 29:898-938.

61. Ligr M, et al. (2010) Tumor suppressor function of androgen receptor coactivator ARA70alpha in prostate cancer. Am. J. Pathol. 176:1891-900.

62. Esquenet M, Swinnen JV, Heyns W, Verhoeven G. (1995) Triiodothyronine modulates growth, secretory function and androgen receptor concentration in the prostatic carcinoma cell line LNCaP. Mol. Cell. Endocrinol. 109:105-11.

63. Lin HY, Davis FB, Gordinier JK, Martino LJ, Davis PJ. (1999) Thyroid hormone induces activation of mitogen-activated protein kinase in cultured cells. Am. J. Physiol. 276:C1014-24.

64. Farwell AP, Dubord-Tomasetti SA, Pietrzykowski AZ, Stachelek SJ, Leonard JL. (2005) Regulation of cerebellar neuronal migration and neurite outgrowth by thyroxine and 3,3',5'-triiodothyronine. Brain Res. Dev. Brain Res. 154:121-35.

65. Fukuda M, et al. (1995) Induction of neurite outgrowth by MAP kinase in PC12 cells. Oncogene. 11:239-44.

66. Witkowski CM, Rabinovitz I, Nagle RB, Affinito KS, Cress AE. (1993) Characterization of integrin subunits, cellular adhesion and tumorgenicity of four human prostate cell lines. J. Cancer Res. Clin. Oncol. 119:637-44.

67. di Blasio L, Droetto S, Norman J, Bussolino F, Primo L. (2010) Protein kinase D1 regulates VEGF-A-induced alphavbeta3 integrin trafficking and endothelial cell migration. Traffic. 11:1107-18.

68. Silva JE, Bianco SD. (2008) Thyroid-adrenergic interactions: physiological and clinical implications. Thyroid. 18:157-65.

69. Dorsa KK, Santos MV, Silva MR. (2010) Enhancing T3 and cAMP responsive gene participation in the thermogenic regulation of fuel oxidation pathways. Arq. Bras. Endocrinol. Metabol. 54:381-9.

70. Méndez-Pertuz M, Sánchez-Pacheco A, Aranda A. (2003) The thyroid hormone receptor antagonizes CREB-mediated transcription. EMBO J. 22:3102-12.

71. Chen WJ, Yeh YH, Lin KH, Chang GJ, Kuo CT. (2011) Molecular characterization of thyroid hormone-inhibited atrial L-type calcium channel expression: implication for atrial fibrillation in hyperthyroidism. Basic Res. Cardiol. 106:163-74.

72. Cole SW, Sood AK. (2012) Molecular pathways: beta-adrenergic signaling in cancer. Clin. Cancer Res. 18:1201-6.

73. Iida M, et al. (2012) Thyroid hormone within the normal range is associated with left ventricular mass in patients with hypertension. J. Am. Soc. Hypertens. 6:261-9.

74. Weltman NT, et al. (2015) Long-term physiological T3 supplementation in hypertensive heart disease in rats. Am. J. Physiol. Heart Circ. Physiol. 309:H1059-65.

75. Mondul AM, et al. (2012) Circulating thyroxine, thyroid-stimulating hormone, and hypothyroid status and the risk of prostate cancer. PLoS One. 7:e47730

76. Wade J, et al. (2013) Psychological impact of prostate biopsy: physical symptoms, anxiety, and depression. J. Clin. Oncol. 31:4235-41.

77. Hassan S, et al. (2013) Behavioral stress accelerates prostate cancer development in mice. J. Clin. Invest. 123:874-86.

78. Huang J, et al. (2013) Implication from thyroid function decreasing during chemotherapy in breast cancer patients: chemosensitization role of triiodothyronine. BMC Cancer. 13:334.

Cite this article as: Delgado-González E, Sánchez-Tusie AA, Morales G, Aceves C, Anguiano B. (2016) Triiodothyronine attenuates prostate cancer progression mediated by $\beta$-adrenergic stimulation. Mol. Med. 22:1-11. 